\title{
Application of Satellite Image Processing Methods for Hydrocarbon Field Search
}

\author{
R.V. Fiodortsev ${ }^{1}$, A.R. Silie Cuenca ${ }^{1,2}$, D.A. Kozhevnikov ${ }^{1}$, V.M. Medina $^{2}$, R. Delgado ${ }^{3}$ \\ ${ }^{1}$ Belarusian National Technical University, \\ Nezavisimosty Ave., 65, Minsk 220013, Belarus \\ ${ }^{2}$ National Experimental University "Antonio José de Sucre" UNEXPO \\ Corpahuaico avenue, Barquisimeto - Lara, 3001 Venezuela \\ ${ }^{3}$ Bolivarian Agency for Space Activities ABAE \\ Francisco Fajardo Avenue, Generalissimo Francisco de Miranda Air Base, La Carlota, Caracas 1064 Venezuela
}

Received 19.08.2019

Accepted for publication 22.11.2019

\begin{abstract}
The object of the study is software methods of the Earth surface images processing obtained from the VRSS-2 satellite to determine the spectral composition of the vegetation cover to detect the presence of carotenoids during prolonged exposure to hydrocarbons.

The photosynthetic pigments of higher plants (chlorophylls, carotenoids and phytobiliproteins) were analyzed. In the chloroplasts of higher plants, chlorophyll and carotenoids are present in a ratio of about 3:1. The presence of hydrocarbons increases the amount of carotenoids. Carotenoids have absorption bands in the blue-violet region from 400 to $500 \mathrm{~nm}$ and a high reflection coefficient in the red-orange and yellow spectral regions, which corresponds to the multispectral MSS operating mode (B2) of the VRSS-2 satellite camera. An analysis of the vegetation growing in the study area of the Puerto Kumarebo settlement showed that the best indicator of the presence of hydrocarbons in the soil is Prosopis juliflora-CUJI with a deep root system of up to $50 \mathrm{~m}$, growing in the study area.

Using ENVI software, a comparative evaluation of the efficiency of photographs image processing was carried out using the normalized relative vegetation index $(N D V I)$ and the structure-insensitive pigment index $(S I P I)$ to detect changes in the color of green vegetation. It has been established that the SIPI index is more applicable for hydrocarbon search tasks. Moreover, the recorded index fluctuations in the area of uniform vegetation at the level of $2.5 \%$ are characteristic of normal growing conditions and cannot serve as evidence of the presence of factors indicating the presence of hydrocarbons in the soil. For a more detailed assessment of the presence of carotenoids in the foliage and the presence of hydrocarbons in the soil, photographs with high optical resolution of objects on the surface are required.
\end{abstract}

Keywords: carotenoids, hydrocarbons, photographs, satellite, ENVI.

DOI: $10.21122 / 2220-9506-2019-10-4-373-381$

\begin{tabular}{|c|c|}
\hline $\begin{array}{l}\text { Адрес для переписки: } \\
\text { P.В. Фёдориев } \\
\text { Белорусский национальный технический университет, } \\
\text { np-m Независимости, 65, г. Минск 220013, Беларусь } \\
\text { e-mail: feоdrw@gmail.com; dmkz.1408@gmail.com }\end{array}$ & $\begin{array}{l}\text { Address for correspondence: } \\
\text { R.V.Fiodortsev } \\
\text { Belarusian National Technical University, } \\
\text { NezavisimostyAve., 65, Minsk220013,Belarus } \\
\text { e-mail:feodrw@gmail.com;dmkz.1408@gmail.com }\end{array}$ \\
\hline Для цитирования: & For citation: \\
\hline $\begin{array}{l}\text { R.V. Fiodortsev, A.R. Silie Cuenca, D.A. Kozhevnikov, V.M. Medina, } \\
\text { R. Delgado. }\end{array}$ & $\begin{array}{l}\text { R.V. Fiodortsev, A.R. Silie Cuenca, D.A. Kozhevnikov, } \\
\text { V.M. Medina, R. Delgado. }\end{array}$ \\
\hline Application of Satellite Image Processing Methods for Hydrocarbon & Application of Satellite Image Processing Methods for Hydrocarbon \\
\hline Field Search. & Field Search. \\
\hline Приборы и методы измерений. & Devices and Methods of Measurements. \\
\hline 2019. - T. 10, № 4. - C. 373-381. & 2019, vol. 10, no. 4 , pp. $373-381$ \\
\hline DOI: $10.21122 / 2220-9506-2019-10-4-373-381$ & DOI: $10.21122 / 2220-9506-2019-10-4-373-381$ \\
\hline
\end{tabular}




\title{
Применение методов обработки изображений фотоснимков со спутников при поиске месторождений углеводородов
}

\author{
Р.В. Фёдорцев ${ }^{1}$, А.Р. Силие Куэнсо ${ }^{1,2}$, Д.А. Кожевников ${ }^{1}$, Медина Виктор Мануэль ${ }^{2}$, \\ Р. Делгадо \\ ${ }^{1}$ Белорусский нацииональный технический университет \\ пр-т Независимости, 65, г. Минск 220013, Беларусь \\ ${ }^{2}$ Национальный экспериментальный политехнический университет имени Антонио Хосе де Сукре, UNEXРО \\ пр-т Корпахуайко, Баркисимето - Лара 3001, Венесуэла \\ ${ }^{3}$ Боливарианское агентство космической деятельности АВАE \\ пр-т Франсиско Фахардо, Авиабаза генералиссимуса Франсиско де Миранда, \\ Ла Карлота, Каракас 1064, Венесуэла
}

Поступила 19.08.2019

Принята к печати 22.11.2019

Объектом исследования являются программные методы обработки изображений участков земной поверхности, полученные со спутника VRSS-2, для определения спектрального состава растительного покрова на предмет обнаружения присутствия каротиноидов при длительном воздействии углеводородов.

Проведен анализ фотосинтетических пигментов высших растений (хлорофиллов, каротиноидов и фитобилипротеинов). В хлоропластах высших растений хлорофилл и каротиноиды присутствует в соотношении примерно $3: 1$. Присутствие углеводородов увеличивает количество каротиноидов. Каротиноиды имеют полосы поглощения в сине-фиолетовой области от 400 до 500 нм и высокий коэффициент отражения в красно-оранжевой и желтой области спектра, что соответствует мультиспектральному MSS режиму работы (B2) фотокамеры спутника VRSS-2. Анализ растительности, произрастающей в исследуемом районе населенного пункта Пуэрто-Кумаребо показал, что наилучшим индикатором наличия углеводородов в почве может являться Prosopis juliflora - CUJI с глубокой корневой системой до 50 м, произрастающая в исследуемом районе.

При использовании программного обеспечения $E N V I$ проведена сравнительная оценка эффективности обработки изображений фотоснимков с применением нормализованного относительного индекса растительности $(N D V I)$ и индекса пигмента, не чувствительного к структуре (SIPI) на предмет обнаружения изменений в цветовой окраске зелёной растительности. Установлено, что для задач поиска углеводородов более применимым является индекс SIPI. При этом зафиксированные флуктуации индекса в области равномерной растительности на уровне 2,5 \% характерны для нормальных условий произрастания и не могут служить доказательством наличия факторов, свидетельствующих о наличии в почве углеводородов. Для более детальной оценки присутствия каратиноидов в листве и наличия углеводородов в почве, требуются фотоснимки с большим оптическим разрешением объектов на поверхности.

Ключевые слова: каротиноиды, углеводороды, фотографии, спутник, ENVI.

DOI: $10.21122 / 2220-9506-2019-10-4-373-381$

\begin{tabular}{ll}
\hline Адрес для переписки: & Address for correspondence: \\
P.В. Фёдориев & R.V. Fiodortsev \\
Белорусский национальный технический университет, & Belarusian National Technical University, \\
пр-т Независимости, 65, г. Минск 220013, Беларусь & Nezavisimosty Ave., 65, Minsk 220013, Belarus \\
e-mail: feodrw@gmail.com; dmkz.1408@gmail.com & e-mail: feodrw@gmail.com;dmkz.1408@gmail.com \\
\hline Для цитирования: & For citation: \\
R.V. Fiodortsev, A.R. Silie Cuenca, D.A. Kozhevnikov, V.M. Medina, & R.V. Fiodortsev, A.R. Silie Cuenca, D.A. Kozhevnikov, \\
R. Delgado. & V.M. Medina, R. Delgado. \\
Application of Satellite Image Processing Methods for Hydrocarbon & Application of Satellite Image Processing Methods for Hydrocarbon \\
Field Search. & Field Search. \\
Приборы и методы измерений. & Devices and Methods of Measurements. \\
2019. - Т. 10, № 4.- С. 373-381. & 2019, vol. 10, no. 4, pp. 373-381. \\
DОI: 10.21122/2220-9506-2019-10-4-373-381 & DOI: 10.21122/2220-9506-2019-10-4-373-381
\end{tabular}




\section{Introduction}

Most effective and reliable of the existing methods of searching for oil and gas is remote sensing of the earth (RS) in the visible and infrared ranges. Filming in the visible range of the spectrum is used to solve the problems of predicting structural traps and evaluating explosive violations. Seismic exploration is still required to estimate hydrocarbon deposits. The probability of discovering new deposits ranges from 0.5 (for poorly studied) to 0.9 (for well-studied) territories. Based on experiments, it was found that in the presence of a small amount of hydrocarbon migrating from deposits to the Earth's surface and accumulating in the soil, in the root system of plants, chemical transformations occur, leading to a change in the number of carotenoids and a change in the color of the leaves. This effect is called "blue shift" and recorded in a relatively narrow spectral range (of the order of $10-20 \mathrm{~nm}$ ). It is most effectively recorded on hyperspectral images obtained from satellites, for example, EO-1 (Hyperion) and others [1].

The purpose of the research is a comparative analysis of various software image processing methods by comparing the normalized relative vegetation index $(N D V I)$ and the structureinsensitive pigment index $(S I P I)$ to determine their effectiveness in detecting changes in the color of green vegetation.

\section{Object of study}

In this work, the object of the study was software methods for processing images of the earth's surface obtained from the VRSS-2 satellite to determine the spectral composition of the vegetation cover to detect the presence of carotenoids during prolonged exposure to hydrocarbons.

Typical elemental composition of oil includes: 82-87\% C (carbon); 11.0-14.5\% H (hydrogen); $0.01-6.0 \% \mathrm{~S}$ (sulfur); $0.001-1.8 \% \mathrm{~N}$ (nitrogen); $0.005-0.35 \% \mathrm{O}$ (oxygen), etc.

Each of the listed elements or their combination has a specific effect on vegetation. Under the prolonged influence of sulfur dioxide, the leaves turn yellow, necrosis forms, and the frost resistance of tree buds decreases. Nitrogen dioxide in large quantities reduces the resistance of plants and leads to their poisoning (leaves become brown). Photochemical reactions taking place with the participation of nitrogen dioxide and hydrocarbons under the action of solar radiation leads to the formation of both peroxide compounds with toxic effects and ozone. The latter slows down photosynthesis in plants and weakens their viability, which leads to a decrease in plant biomass [2].

Photosynthetic pigments, which absorb the energy of light in photosynthesis reactions, are indicators of such processes. There are three main types of photopigments: chlorophyll, carotenoids and phytobiliproteins. Plant chlorophyll includes four species $a, b, c$ and d. Higher plants contain both $\mathrm{a}$ and $\mathrm{b}$, chlorophyll $\mathrm{c}$ and $\mathrm{d}$ are present in algae, and photosynthetic bacteria contain bacteriochlorophyll. In addition to absorbing and transmitting light energy, fat-soluble carotenoid pigments can also dissipate energy in strong light and have a photoprotective effect that protects chlorophyll from damage. Chlorophyll and carotenoids are always present together in the chloroplasts of higher plants in a ratio of about $3: 1$. In autumn or in a poor environment, chlorophyll in the leaves decomposes more easily, and its amount decreases, and carotenoids are relatively stable. Carotenoids have absorption bands in the blue-violet region from 400 to $500 \mathrm{~nm}$. They do not absorb red-orange and yellow light and therefore look orange or yellow.

Figure 1 shows the absorption spectra of the most common pure photopigments: chlorophyll $\mathrm{A}$ bacteria (curve 1), chlorophyll A plants (curve 2), chlorophyll B (curve 3), $\beta$-carotene (curve 5) and phycoerythrobilin (curve 4) [3].

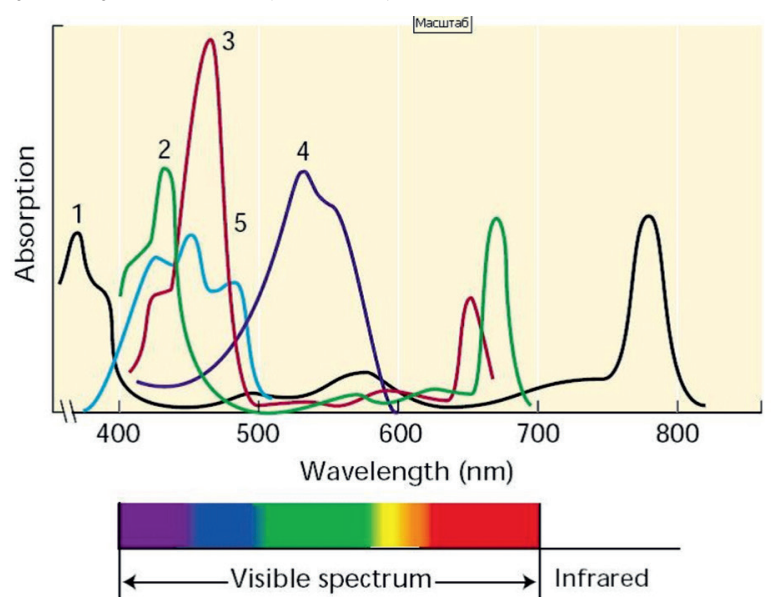

Figure 1 - Spectral characteristics of plant photopigments: 1 -chlorophyll A bacteria; 2-chlorophyll A plants; 3 - chlorophyll B; 4 - phycoerythrobilin; 5 - $\beta$-carotene

Three groups of compounds belong to carotenoids [4]:

1) orange or red carotene pigments $\left(\mathrm{C}_{40} \mathrm{H}_{56}\right)$;

2) yellow xanthophylls $\left(\mathrm{C}_{40} \mathrm{H}_{56} \mathrm{O}_{2}\right.$ and $\mathrm{C}_{40} \mathrm{H}_{51} \mathrm{O}_{4}$ ); 
3) carotenoid acids - oxidation products of carotenoids with a shortened chain and carboxyl groups (for example, $\mathrm{C}_{20} \mathrm{H}_{24} \mathrm{O}_{2}$ - crocetin having two carboxyl groups).

The mild tropical and subequatorial climate, as well as favorable weather conditions in Venezuela, contribute to the great diversity of vegetation growing on its territory. The air temperature changes little during the year, the differences in the seasons are the amount of precipitation. Only in the studied northern part of Venezuela - the state of Falcón grows about 30 species of trees. To analyze the presence of hydrocarbons in the soil from growing plant species, it is advisable to consider those that differ in a deeply developed root system.

A detailed analysis showed that the following four types are best suited:

-(Bursera tomentosa - Caricarito, Isicagua de burro),

-(Capparis odoratissima - Olivo),
- (Prosopis juliflora - CUJI) root system: light, 1-2 processes, up to $7 \mathrm{~m}$ wide and 15 to $50 \mathrm{~m}$ deep,

-(Conocarpus erectus - Mangle botón) root system: the processes are lateral and thin, weak and fragile, have cork bark.

\section{Correlation of image quality of photographs with physical parameters of the Earth's atmosphere}

Images from the VRSS-2 satellite provided by the Bolivarian Agency for Space Activities ABAE were used as initial data for image processing. The satellite passes over Venezuela three or four times every 24 hours, covering the same area in 101 days in Nadir [5]. The satellite contains two different cameras: a high resolution camera (HRC) and an infrared camera (IRC). The highest resolution is $0.98 \mathrm{~m}$ GSD in panchromatic mode and $4 \mathrm{~m}$ GSD in the multispectral range (Table).

Table

Spectral ranges of VRSS-2 cameras

\begin{tabular}{lcccc}
\hline Designation & $\begin{array}{c}\text { Multispectral } \\
\text { MSS, nm }\end{array}$ & $\begin{array}{c}\text { Short wave infrared } \\
\text { IRC-1, nm }\end{array}$ & Long wave infrared IRC-2, $\mu \mathrm{m}$ & $\begin{array}{c}\text { Panchromatic } \\
\text { PAN, nm }\end{array}$ \\
\hline B1 & $450-520$ & $900-1100$ & $10,3-11,3$ & $500-800$ \\
B2 & $520-590$ & $1180-1300$ & $11,5-12,5$ & - \\
B3 & $630-690$ & $1550-1700$ & - & - \\
B4 & $770-890$ & - & - & - \\
\hline
\end{tabular}

Infrared cameras have a resolution of $60 \mathrm{~m}$ (long wave channel) and GSD $30 \mathrm{~m}$ (short wave channel), which is 10 spectral ranges.

ABAE's standard VRSS-2 products consist of a quantitative, calibrated and scaled series of digital levels (DNs) that represent multispectral image data obtained using HRC (high-resolution camera) and IRC (infrared camera). HRC sensor ranges (PAN and MSS) and IRC are displayed in 10 bits in unencrypted format and can be scaled to reflectance and/or upper atmosphere (TOA) values. Radiometric correction includes the restoration of lines or pixels lost when shooting, in addition to correcting the image strip. Spectral radiation or brightness level is determined from the expression:

$$
\begin{aligned}
& L_{\lambda}=\frac{D N}{K_{\text {band }}}-\frac{B_{\text {band }}}{K_{\text {band }}} ; \\
& L_{\lambda}=\frac{D N}{K_{\text {band }}}-\frac{C_{\text {band }}}{K_{\text {band }}},
\end{aligned}
$$

where $L_{\lambda}$ - spectral radiation (W/m ${ }^{2}$ cf. microns); $D N$-digital value of the image. The digital level $(D N)$ is a numerical value that encodes each pixel and determines the intensity of the display of a gray or color image on the monitor screen.

$B_{\text {band }}, C_{\text {band }}$ and $K_{\text {band }}-$ scale factors for each band present in the metadata. The values of the constants $B, C$, and $K$ of the radiometric coefficients are indicated in the metadata file in the Calibration Parameters block, together with a set of loaded bands.

When obtaining brightness values, it can be used repeatedly to continue the calculation of reflectivity, which allows to obtain more accurate results for vegetation indices determining.

The following equation is used to convert the digital levels $(D N)$ to reflectance values (TOA) in the upper atmosphere obtained by the IRC-2 sensor:

$\rho_{\lambda}=\frac{\pi L_{\lambda} d^{2}}{E S U N_{\lambda} \cos \theta}$, 
where $\rho_{\lambda}$-spectral reflectance; $d$-distance from Earth to the Sun in astronomical units $-\mathrm{UA}=149597870 ; E S U N_{\lambda}-$ solar radiation $\left(\mathrm{W} / \mathrm{m}^{2}\right.$ microns); $\theta=51.853^{\circ}-$ sunny elevation.

In this case, the brightness temperature $(T)$ is determined by the expression:

$$
T=\frac{K_{2}}{\ln \left(\frac{K_{1}}{L_{\lambda}}+1\right)}, \quad(\mathrm{K}),
$$

where $K_{2}$ - thermal constant for each band present in the metadata $(\mathrm{K}) ; K_{1}$ - thermal constant for each band present in the metadata (W/m $\mathrm{m}^{2} \mathrm{cf}$. microns).
In particular, for the IRC-2 sensor, the current values of thermal constants are presented in the metadata in the section of thermal constants.

\section{Selecting a hydrocarbon search area and satellite images}

There are four oil basins in Venezuela: Maracaibo (the largest field in the north-west of the country); Apure Falcon; Oriental. The following deposits have been discovered: Shelf Bolivar, Bombal, Karabobo, Tukupita, Khunin (Figure 2) [6].

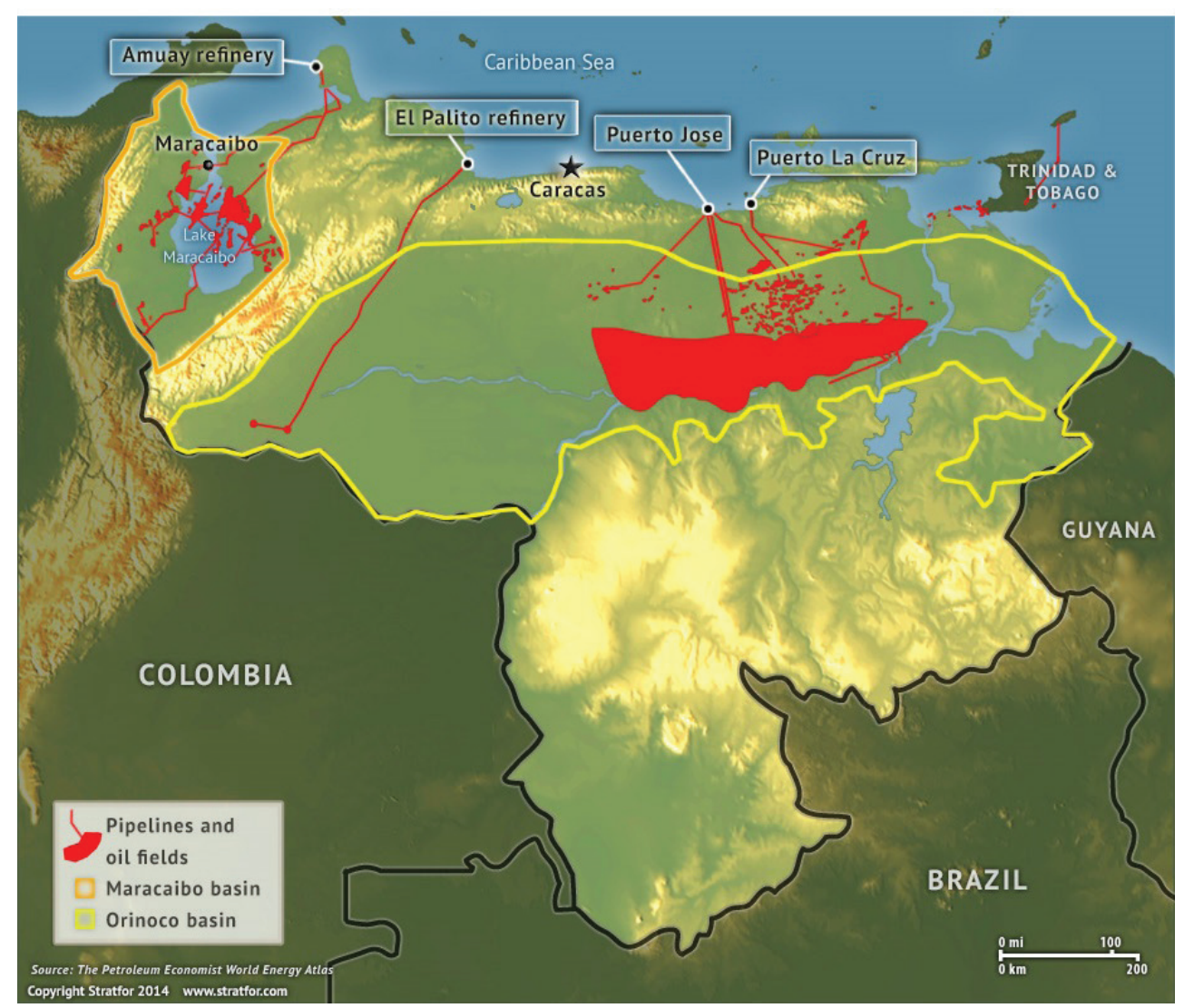

Figure 2 - The layout of hydrocarbon deposits in the Republic of Venezuela

Figure 3 shows an image of the area around Puerto Kumarebo, the capital of the Zamora municipality of Falcon, Venezuela. The coordinates

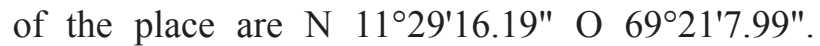
The Kumarebo Field is located in the northern part of Falcon, $42 \mathrm{~km}$ east of the city of Coro and $5 \mathrm{~km}$ south of the Caribbean Sea, Tucupido. This field is located in the central-eastern sector of the Falcon Basin, east of the La Vela anticline and west of the Ricoa structure. The oil discovered in the Kumarebo field is ultra-light and has excellent quality (density $0.78-0.82 \mathrm{~g} / \mathrm{cm}^{3}$, gas condensate on average $47.5^{\circ}$
API). Some sediments contain $65^{\circ}$ API condensate. Currently, Kumarebo has 13,000 active wells, production of which provides 1,885 million barrels per day. This region is geologically connected with the basin of Lake Maracaibo [7].

\section{Software methods for processing satellite images}

Today, the market has a fairly large number of commercial (paid) software designed for processing and analysis of Earth remote sensing 
data. The most famous software products and raster graphic editors include: ERDAS-Imagine (USA), IDRISI (USA), ENVI (USA), Socet-GXP (USA), eCognition (Germany), ER Mapper (Austria), PCI Geomatica (Canada) and others. The performance and functionality of each package is due to advances in computer technology, which is mainly determined by the need for efficient processing of large amounts of data. Many of these software products are compatible with the platform of the Windows operating system [8]. The cost of these programs varies from $\$ 25,000$ to $\$ 100,000$.

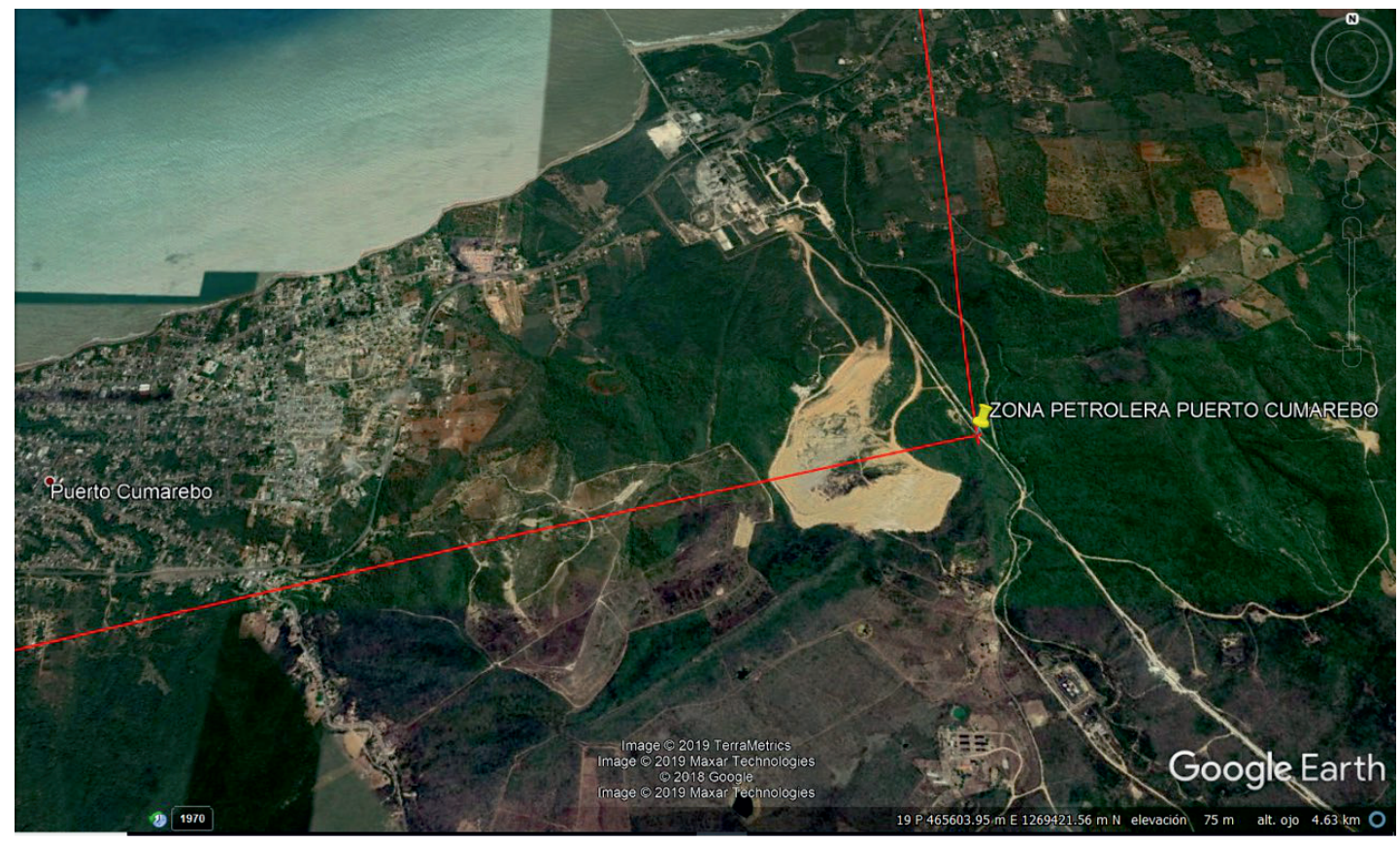

Figure 3 - Puerto Kumarebo Photographic Area for the Search for Hydrocarbons

An alternative approach is the development of free open source software for building geographic information systems (GIS), which has accelerated significantly in recent years. The most common are: GRASS-GIS (USA), gvSIG (Espanola), InterImage (USA), ILWIS-Open (Germany), Opticks (Ball Aerospace \& Technologies Corp. USA), ORFEO Toolbox (OTB) (France), PolSARPro (France), Sentinel Toolbox (France), Quantum GIS and SCPQGIS (Plugin) (USA), SAGA-GIS (Germany), Sentinel Hub QGIS (Plugin) (Slovenia), SoPI (Argentina), Whitebox Geospatial Analysis Tools (Canada), ePhoto Z300 and others. The specified software has a number of functionalities for working with Earth remote sensing data: calculation of statistics and histograms, filtering, classification, correction and segmentation of satellite images, detection of changes, calculation of vegetation indices and monitoring of fires, changes in land use of the land cover, modeling of changes in the earth coating [9].

Research was conducted using ENVI software.

\section{The ratio of the studied spectral parameters and color coordinates of the photograph}

To carry out a spectral analysis of images obtained from a spacecraft in panchromatic and monochromatic modes, it is necessary to precalibrate the studied wavelength relative to the color coordinates in the RGB system (Figure 4).

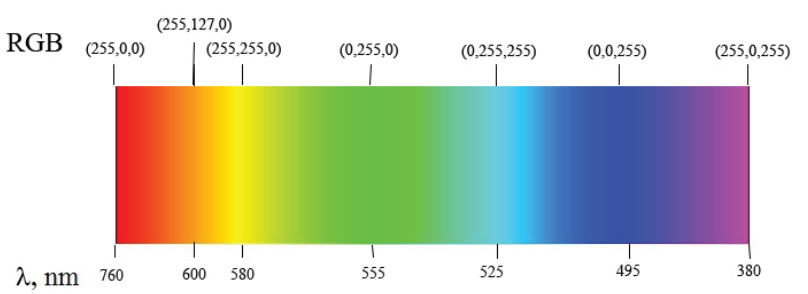

Figure 4-Correspondence of the visible region of the spectrum to the RGB color system

To date, there are a fairly large number of different conversion techniques. In our case Dan Bruton's NetPBM software (based on FORTRAN) was used, taking into account the width, height, depth and gamma of the original image in the RGB 
system and its linear interpolation relative to a given wavelength [10].

\section{Selection of vegetation status assessment index}

Classical methods for estimating the amount of photosynthetically active biomass are carried out through the Normalized Difference Vegetation Index (NDVI). This index can take values from -1 to 1 , calculated by the absorption and reflection by the plants of the rays of the red and near infrared zones of the spectrum. The calculation of the majority of vegetation indices is based on the two most stable (independent of other factors) sections of the curve of the spectral reflectivity of plants. The red zone of the spectrum $(0.62-0.75 \mu \mathrm{m})$ accounts for the maximum absorption of solar radiation by chlorophyll, and the near infrared zone $(0.75-1.3 \mu \mathrm{m})$ has the maximum energy reflection of the leaf cell structure. High photosynthetic activity (usually associated with a large phytomass of vegetation) leads to lower values of reflection coefficients in the red zone of the spectrum and large values in the near infrared region of the spectrum. The ratio of these indicators to each other allows you to clearly separate the vegetation from other natural objects [11].

Figure 5 shows a fragment of the image of the Earth's surface (N $11^{\circ} 29^{\prime}-\mathrm{N} 11^{\circ} 25^{\prime}$; W 69 $25^{\circ}$ W $69^{\circ} 20^{\prime}$ ) obtained by VRSS-2. The frame highlights the area $(5000 \times 4000 \mathrm{~m})$ selected for the analysis of vegetation for the presence of hydrocarbons in the soil. Together with the forest in the region there are cities and roads, which will qualitatively assess the applicability of vegetation indices.

Figure 5 shows an array of the obtained NDVI indices at different limits of the range. For healthy and dense vegetation, the index value equal to $N D V I=0.5-0.8$ is considered to be typical.

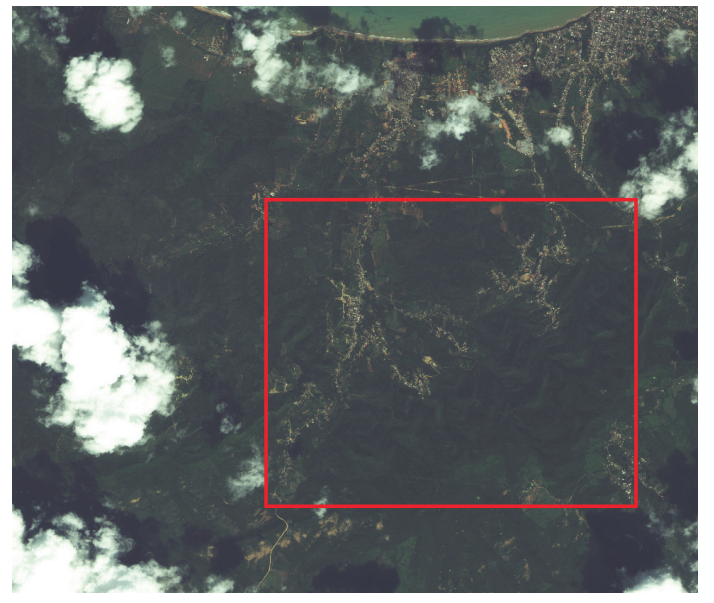

Figure 5 - Image fragment from VRSS-2 (area southwest of Puerto Kumarebo)
Three ranges of the index were chosen for evaluation: $-1.0 \ldots 1.0$ (Figure $6 a$ ); $0 \ldots 1.0$ (Figure $6 b) ; 0.5 \ldots 1.0$ (Figure 6c).

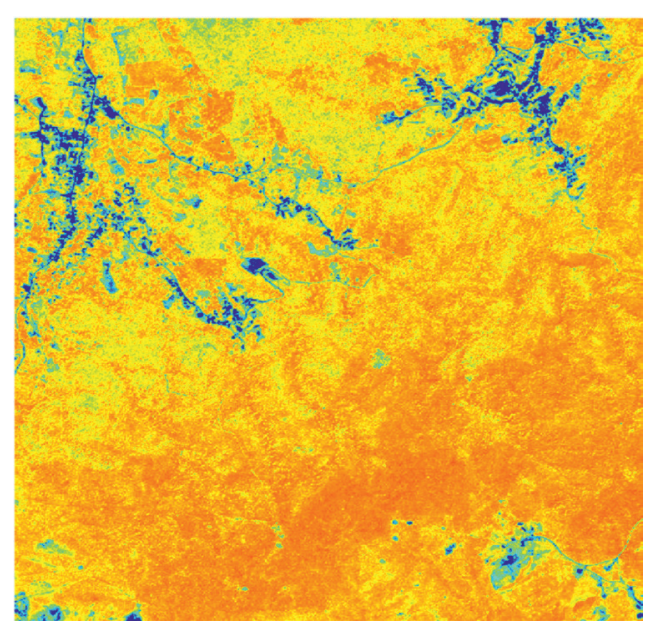

$a$

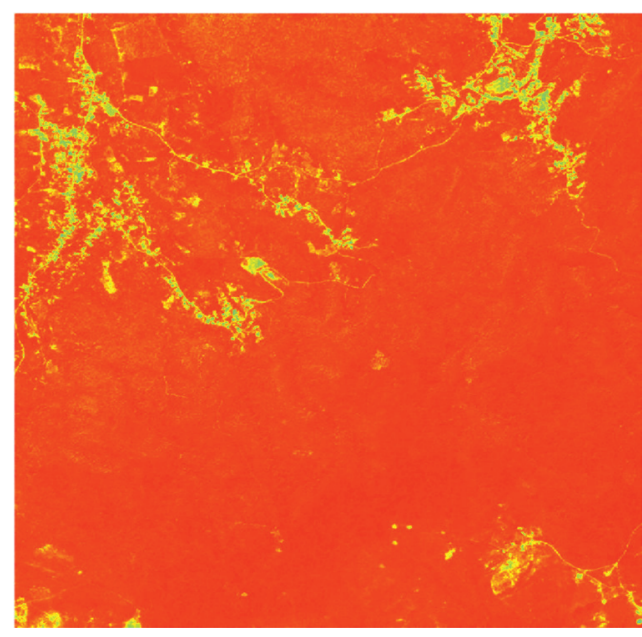

$b$

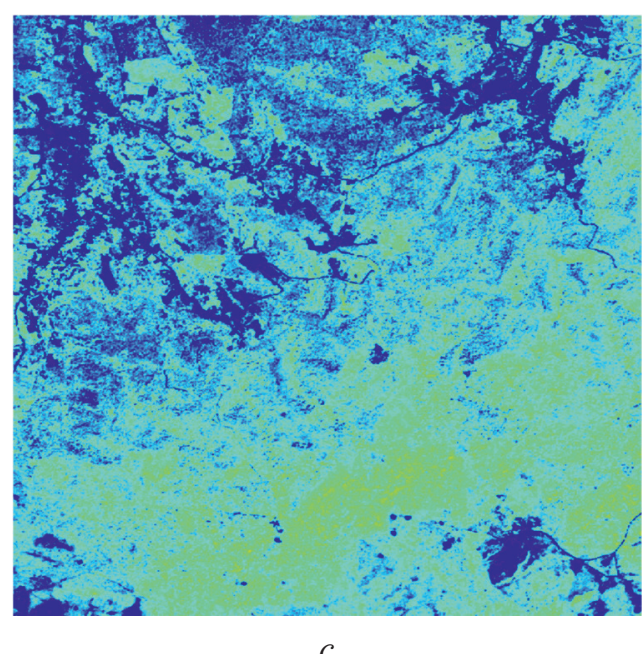

Figure 6 - Arrays of NDVI indices of the selected area with different contrasts: $a-(-1,0) \ldots 1,0 ; \quad b-0 \ldots 1,0$; $c-0,5 \ldots 1,0$ 
In Figure $6 a$ (in the upper part) in blue, significant areas of cities and roads are clearly distinguished - the lower boundary of the contrast. Against this background, areas of vegetation merge into a single massif (yellow-orange zone). For a more detailed assessment of the area of the plant mass, the contrast range was narrowed initially to $0 \ldots 1$ (Figure $6 b$ ) and subsequently to a narrower range of $0.5 \ldots 1$ (Figure $6 c$ ). Analysis of the last image shows that the vegetation in this area has a heterogeneous color; however, for a more detailed assessment of the presence of carotenoids in the foliage and the presence of hydrocarbons in the soil, photographs with a high optical resolution of objects on the surface are required.

For this area, a comparative analysis of the efficiency of displaying the state of vegetation by the pigment index that is not sensitive to the SIPI structure (Structure Insensitive Pigment Index) was carried out. This index is used to monitor the condition of plants in regions with a high variability of the canopy structure or leaf area index, for early detection of plant diseases or other causes of stress. The ratio of volumetric carotenoids to chlorophyll is determined by the general formula:

SIPI $=($ NIR - blue $) /($ NIR - red $)$.

The overall SIPI range is from 0 to 2 . High SIPI values (increased carotenoid content and decreased chlorophyll content) are often indicative of plant disease, which is associated with loss of chlorophyll in plants. Moreover, for healthy vegetation, the index value varies from 0.8 to 1.8 .

Figure 7 shows an array of SIPI indices with different contrast values: $0-2.0$ and $0.95-1.0$. An analysis of Figure $7 a$ shows that the areas of cities and roads have a significantly larger index value (yellow-green and red zones), similar to the data obtained in Figure $4 a$ for NDVI, and a lower uniform value for the area with predominant vegetation (blue zone). Increasing the lower border of the contrast of the SIPI index to $0.95-1.0$ (Figure 7b) allows almost completely eliminating the urban infrastructure (red-brown zone) and highlighting areas with heterogeneous green vegetation (yellowgreen and blue zones) on the forest. However, with absolute changes within $2.5 \%$, one cannot unequivocally express the possibility of the influence of soil hydrocarbons on this index.

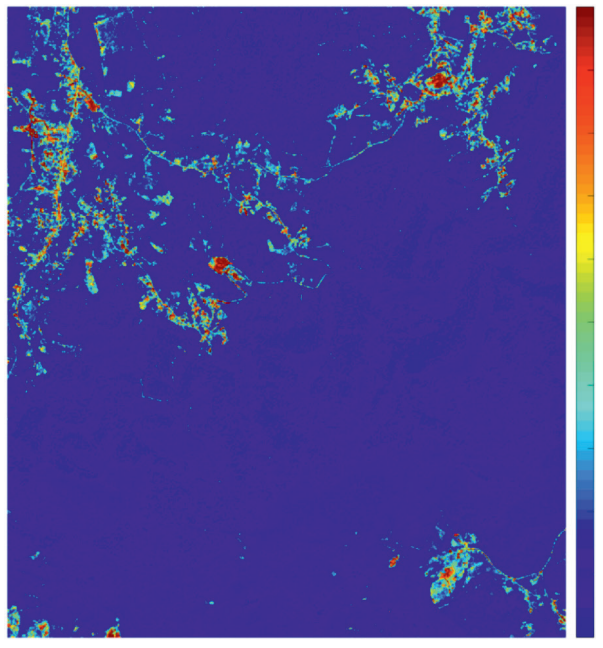

$a$

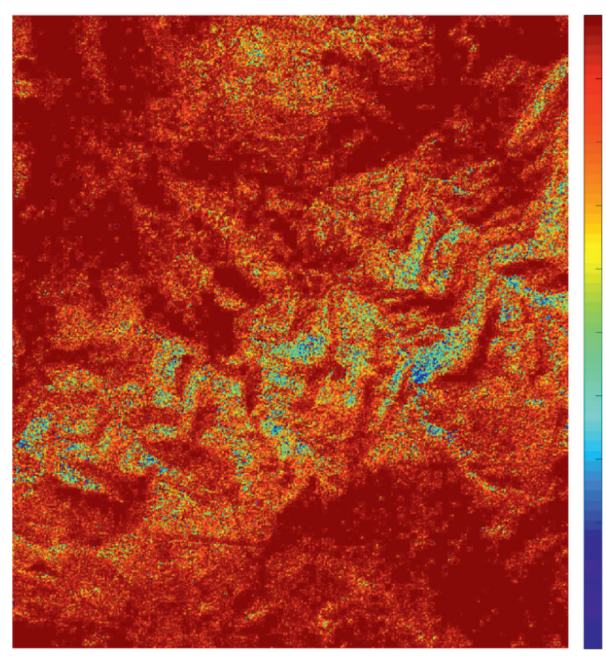

$b$

Figure 7 - Arrays of SIPI indices of the selected area at different contrasts: $a-0-2,0 ; b-0,95-1,0$

As can be seen from Figure $7 b$, the SIPI index is uneven over the forest area, which indicates a different state of vegetation.

\section{Conclusion}

Using ENVI software, a comparative evaluation of the efficiency of image processing of photographs was carried out using the normalized relative vegetation index and the structure-insensitive pigment index (SIPI) to detect changes in the color of green vegetation. It was found that the SIPI index is more applicable for hydrocarbon search tasks. Moreover, the recorded index fluctuations in the area of uniform vegetation at the level of $2.5 \%$ are characteristic of normal growing conditions and cannot serve as evidence of the presence of factors indicating the presence of hydrocarbons in the soil. For a more 
detailed assessment of the presence of carotenoids in the foliage and the presence of hydrocarbons in the soil, photographs with high optical resolution of objects on the surface are required.

An analysis of vegetation species with a deep root system that grows in the studied region of Puerto Kumarebo (Venezuela), which best reflect the presence of chemical elements in the soil indicators of hydrocarbons.

\section{References}

1. Trofimov D.M. Remote sensing: new technologies - new opportunities for oil and gas exploration. Geomatics, 2009, no.1, pp. 17-24.

2. Aerosols of Siberia. Integration projects. Ed. K.P. Kutsenogogo. FSUE Publishing House SB RAS, 2006, iss. 9. -555 p.

3. Lincoln Taiz, Eduardo Zeider. Plant Physiology. Sinauer Associates, 2002, chapter 7, 690 p. (P. 115). ISBN: 0878938230.

4. Cherepanov A.S., Druzhinina E.G. Spectral properties of vegetation and vegetation indices. Geometry, 2009, no. 3, pp. 28-32.

5. VRSS-2 or Antonio José de Sucre is Venezuela. https://www.n2yo.com/satellite/?s=42954
6. Mountain Encyclopedia / Ch. ed. E.A. Kozlovsky; Ed. col.: M.I. Agoshkov, N.K. Baibakov, A.S. Boldyrev et al. Sov. encyclopedia, Geosystem, 1984, vol. 1, 560 p.

7. Renny Calleja. Cuenca geológica Falcón en Venezuela.Parte2.Monografía.CUENCAPETROLÍFERA DE FALCÓN. UNIVERSIDAD DEL ZULIA, 2002, 28 p. https://rdv-files.nyc3.cdn.digitaloceanspaces.com/pub/ pdf/files_pdf/5/8/5/00031585.pdf

8. Al-Wassai F.A., Kalyankar N.V. Image fusion technologies in commercial remote sensing packages. Journal of Global Research in Computer Science, 2013, 4(5), pp. 44-50.

9. Quirós E., Polo M.E. Recursos abiertos de información geográfica para investigación y documentación científica. Revista Española de Documentación Científica, 2018, vol. 4, no. 3, pp. 126138. DOI: $10.3989 /$ redc.2018.3.1512

10. Dan Bruton. Approximate RGB values for Visible Wavelengths, 1996. Internet: http:/www.physics. sfasu.edu/astro/color/spectra.html

11. Spectral Indexes on Top of NDVI To Make Your Vegetation Analysis Complete. Earth Observing System EOS. 22.02.2019. https://eos.com/blog/6-spectralindexes-on-top-of-ndvi-to-make-your-vegetationanalysis-complete/?utm_source=Email\&utm_medium= educationalcontent\&utm_campaign=button 